\title{
A THEMATIC DICTIONARY AS A SOURCE OF CULTURAL COMPETENCE (USING THE EXAMPLE OF A CHINESE-POLISH DICTIONARY)
}

(THIS ARTICLE WAS TRANSLATED FROM POLISH BY JAKUB WOSIK)

Keywords: cultural competence, linguaculture, socioculture, teaching Polish as a foreign language, thematic dictionary

\begin{abstract}
This article discusses a thematic dictionary of a specific language pair (Chinese-Polish in this case) as a teaching aid useful in learning a language and its culture. In the search for a place for the thematic dictionary in language teaching, the author refers to the notion of cultural competence and notions associated with introducing it into the teaching process as cultural competence covers both vocabulary and knowledge (linguaculture), and the interpretative rules and elements of the study of the reality of people and institutions within the area of socioculture. The contents of those areas of culture of a community are discussed in the theoretical studies devoted to teaching Polish as a non-native language and in the curricula of teaching Polish as a foreign language. Those activities become focussed, e.g. in the required standards which refer to individual levels of language proficiency.

A thematic dictionary may serve as a source for introducing elements of culture considering the stock of vocabulary which illustrates the differences in languages and cultures. In the discussion of the Chinese-Polish thematic dictionary, the author focusses on the description of macrostructures, the inclusion of selected thematic fields, and indicates its utility in increasing one's proficiency in the lexis which illustrates the extra-linguistic reality.
\end{abstract}

In the modern theory and practice of teaching Polish as a non-native language there is a conviction that teaching linguistic competences (knowledge of the inflectional system, syntactic structures and the lexis of the language) should accompany the teaching of cultural competences. Some researchers use for this the term sociolinguistic competence, which covers both social and cultural competences (Żydek-Bednarczuk 2012, p. 21). While avoiding the debates surrounding the extent of intercultural competences, it is worth drawing on findings which indicate the areas of knowledge and skills which should be inc-

*e.sekowska@uw.edu.pl, University of Warsaw, Faculty of Polish Studies, Institute of Applied Polish Studies, ul. Krakowskie Przedmieście 26/28. 02-927 Warsaw. 
luded within the process of cultural education (they refer to both learners and teachers):

- holding specific knowledge about one's own culture and the other culture, and knowledge about social groups and the differences arising in interactions. That knowledge covers history, everyday conduct, traditions, customs, forms of address, and modes of discussion. "At this point one might find it useful to apply general knowledge on intercultural communication regarding individualistic and collectivistic cultures, high and low context cultures, feminine and masculine cultures, or even cultures of linear, flexible or cyclical time" (Żydek-Bednarczuk 2012, p. 24);

- acquisition of skills for interpreting one's own culture within the context of the other culture and interpreting the other (foreign) culture within the context of one's own. That mainly applies to finding similarities and differences between cultures;

- learning the skills of perceiving one's own attitude and behaviour within the context of both cultures. To that end, knowledge on verbal and non-verbal behaviours in specific communicational contexts, e.g. regarding gestures, conflict situations, and ritualistic behaviour, is useful;

- developing the skills of a conscious approach to otherness and separateness, and of critical cultural awareness (see Żydek-Bednarczuk, 2012, p. 24) ${ }^{1}$.

The findings presented have arisen from discussions on the need to introduce cultural notions into the teaching of Polish as a non-native language. They have been raised since the 1990s and they apply not only to the inclusion of the canonical set of Polish culture in teaching Polish as a non-native language, but also the means of implementing it in the teaching of selected cultural elements (cf.: Garncarek 2005; Zarzycka 2005).

A summary of the debate on the place of culture in teaching Polish as a non-native language was provided in a volume edited by W. Miodunka entitled Kultura w nauczaniu języka polskiego jako obcego. Stan obecny - programy nauczania - pomoce dydaktyczne (Krakow 2004). Many materials prior to the release of the volume applied to preparing the process of certification of proficiency in Polish as a foreign language, which was launched in 2004. The direction in which those works were progressing were discussed in the document: Standardy wymagan odnoszacych się do poszczególnych poziomów biegłości językowej w zakresie znajomości języka polskiego issued as a Resolution of the Minister of Science and Higher Education of 30 March 2016.

In line with the article's title, allow me to focus on the contents of two catalogues: Katalog intencjonalno-pojęciowy [Intentional and notional catalogue] and Katalog tematyczny [Thematic catalogue]. The former, which covers sociocultu-

${ }^{1}$ This article is a considerably altered and extended version of a text I submitted for publication in the Philologica series of the Bratislava: Univerzita Komenského publishing house. 
ral issues ${ }^{2}$, includes selected speech acts, e.g. politeness-based conventions, informing and inquiring, confirming and denying, expressing emotions; and actions based on applicable linguistic structures in specific communicational situations (contact with a colleague, friend, guest, family member, client, patient, etc.). Their scopes increase as new levels of language proficiency are achieved.

The thematic catalogue, as per the definition of thematic vocabulary, covers lexical circles which refer to specified realities. The number of circles increases at specific stages of teaching and testing Polish as a foreign language: at the A1 level there are 13 circles, and there are 18 circles at the $\mathrm{C} 2$ level. For example, at the $\mathrm{A} 1$ level, specialists list the following thematic areas: 1. Humans; 2 . Home, flat, surroundings; 3. Everyday life; 4. Free time, entertainment; 5. Travel; 6. Interpersonal relations; 7. Health; 8. Shopping; 9. Food and drink; 10. Services; 11. Places; 12. Natural environment; 13. Traditions, customs, holidays. Further circles are added at the B1 level: Social relations; General topics; and at the $\mathrm{C} 2$ level: Science and technology; The media; Education. When analysed, they display a concentric pattern of expanding contents.

Some vocabulary items in the listed thematic circles fit the linguacultural space which, according to Grażyna Zarzycka, a researcher of the area of culture in teaching Polish as a foreign language, covers the following elements of Polish culture: - architecture and the cultures of Polish cities and towns; - persons considered icons of Polish culture, art, and science; - Polish Nobel prize laureates; - Polish traditions. The so-called cultural part also includes: the linguistic image of values, symbols, and meanings particular to an area of language; names of people, traditions, and places, and the conventionalised linguistic and idiomatic means, sayings, proverbs, quotations, winged words, and longer texts through which one can interpret a culture or subcultures (cf. Zarzycka 2008, p. 151).

It is not enough to establish the extent of linguaculture - it must also be introduced during classes. Towards that end, Polish teachers use various strategies: they use purpose-developed textbooks in which linguistic information is accompanied by details about the culture (everyday life, attitudes, ritualised behaviour, forms of address); they introduce Polish films, in which one can find examples of workplace relations, relations between the sexes, religious behaviour, humorous behaviour, etc.; they use works of literature and advertising texts; they organise social events with the intention of helping learners experience Polish customs, e.g. St. Andrew's Eve or decorating the Christmas tree; and they hold lectures on

\footnotetext{
${ }^{2}$ Socioculture is defined as the culture of the social life of a community: "It emerges in teaching material when it conveys knowledge on the community of a cultural area (the area of a language), in particular regarding everyday life, interpersonal relations and values, and the behaviour important for the functioning of the community," (Zarzycka 2008, pp. 148-150). Socioculture consists of the elements of knowledge of people and institutions and the rules of interpretation helpful in decoding values, conventions, and rituals important in a community, e.g.: ceremonial year, politeness rules, expressions of social distance, etc.
} 
selected issues. In the final case, a thematic dictionary may constitute an efficient teaching aid. It is a particularly helpful kind of publication as learners who speak other languages are often distant from Poland not only in geographical, but also cultural terms: such a dictionary associates vocabulary with the reality of a specific cultural context, and groups words within lexical and semantic fields, which constitute a reflection of the extra-linguistic reality, which may help them realise the similarities and differences between cultures.

Thematic bilingual dictionaries with a foreign-language-education focus are common nowadays. They are known well in West European and Slavic lexicographies (Batko-Tokarz 2019, pp. 69-70). Some have been studied extensively, e.g. Francusko-polski stownik tematyczny [French-Polish Thematic Dictionary], Maty stownik tematyczny angielsko-polski [Small English-Polish Thematic Dictionary], Wielojęzyczny stownik wizualny. Leksykon tematyczny [Multilingual Visual Dictionary. A Thematic Lexicon] (see Batko-Tokarz 2019, p. 70). They are mostly practical in nature - they constitute a good tool for finding the required information in particular life situations, and they help one increase one's language proficiency. In selecting thematic circles, apart from the obvious scopes which group vocabulary related to the aspects of living, authors usually apply the filter of significance for modern readers: they include current vocabulary which refers to modern world issues, e.g. mad cow disease, drug addiction, alcoholism, terrorism, environmental protection, natural catastrophes and disasters (cf. Zaręba, Kochan 2002, p. 7; Masoit, Rutkovska, Patiejūnienè 2007, pp. 9-10). Those dictionaries use simple modes of defining terms, i.e. by providing lexical equivalents or definitions based on meaning related to the existing reality.

Among the many such works there is also the Chińsko-polski stownik tematyczny (2013) [Chinese-Polish Thematic Dictionary] published by The Commercial Press and edited by Zhang Wenying, Sun Shuxue, Ao Dann, and Zou Yanyan; the framework of the entries and their Polish versions were developed by a team of specialists. It is a publication worth studying as it is the first dictionary in this language pair published in China. I infer that the dictionary was created in response to increased Polish-Chinese contacts in various areas, including an increase in the number of Polish studies centres in China. ${ }^{3}$ The dictionary's release is the more significant considering that Polish is not the most popular language in the world.

The categorisation of reality in the dictionary has been devised from the Chinese perspective, yet it is also useful for the students of Polish studies for indicating the similarities and differences between the two languages and their cultures.

The dictionary has a two-stage hierarchy, which covers 5 main groups: Everyday life; Social life; Public affairs; Economic activity; and Social and natural

${ }^{3}$ In continental China, there are 16 Polish studies institutes with various focusses; the oldest one is the Chair of the Polish Language at Beijing Foreign Studies University (1954); in 2014-2019, Polish studies units were established in Guangzhou, Shanghai, Dalian, and Sichuan. 
sciences. Within them, there are several subgroups. The fields aggregate practical vocabulary necessary in everyday contacts, as well as specialist lexis. Group 5 includes an Annex which contains the names of countries, capitals, and currencies. The dictionary also includes an Alphabetical index of entries, which facilitates finding the required names in a group. As the brief Foreword states: "The dictionary is built around a lexicon of everyday life issues, and its distinguishing feature is the large number of new words. The entries are organised in a general to specialised order, and their selection reflects the high pace of changes occurring in vocabulary typical in modern dictionaries" (Chińsko-polski stownik tematyczny 2013). The dictionary includes 25,000 entries. For foreigners' ease of use, entries in Chinese include Latin transliterations.

The thematic macrostructure has been a feature of multilingual dictionaries intended for school use. Specialised lexicons were promoted in the past by John Amos Comenius, who created a series of school dictionaries organised in such a way to associate the expansion of one's knowledge with noticing the surrounding reality and with a broader view of the world (Otwinowska 1990, p. 783). Today, the application of thematic divisions is justified in a similar manner. The author of the thematic division in Wielki stownik języka polskiego (available online at http: www.wsjp.pl) wrote thus about introducing her classification: "The identified thematic fields may indicate the image of extra-linguistic reality in its common perception, thus indicating the preferred values and hierarchies which exist in the

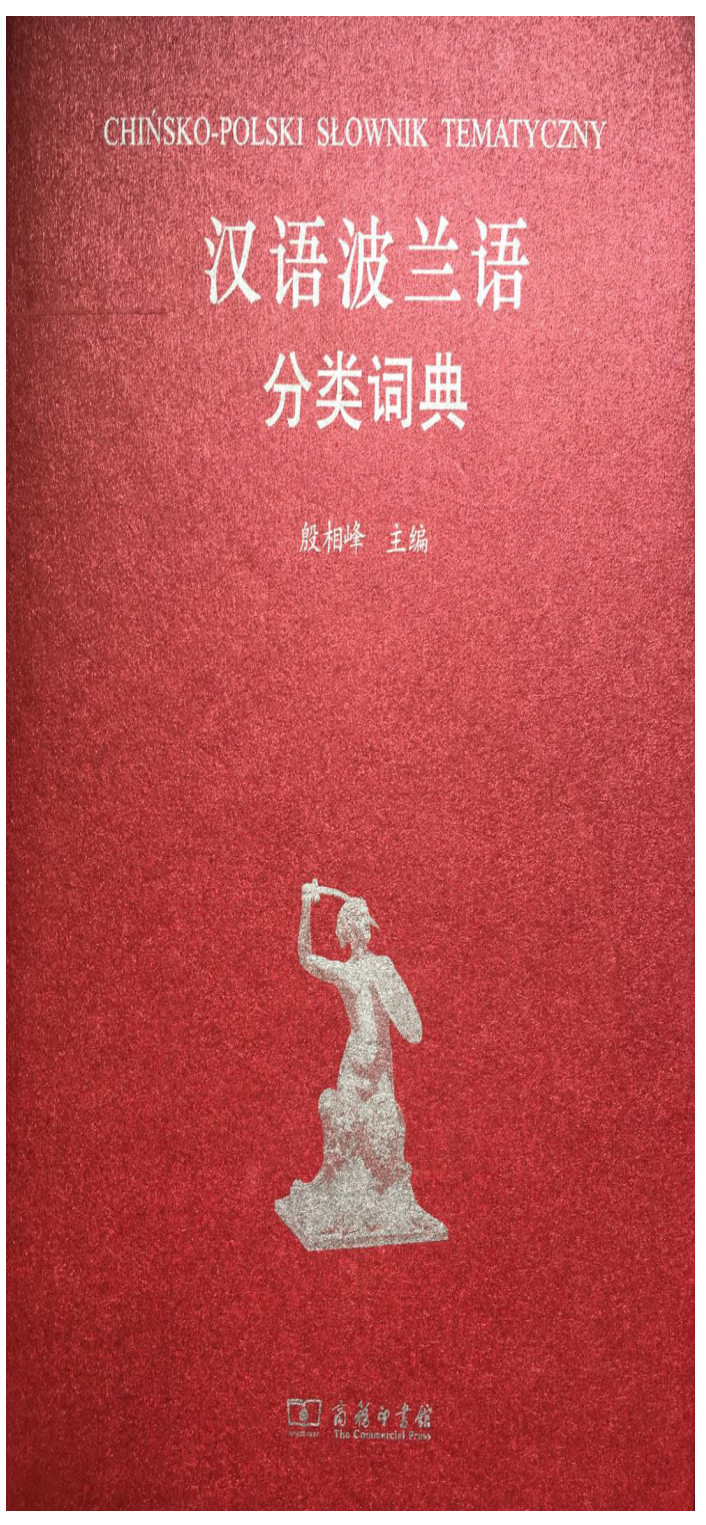

The cover of Chińsko-polski stownik tematyczny 
culture of everyday life, which differ considerably from the academic hierarchy of reality" (Batko-Tokarz 2008, p. 31).

Comparative semantics studies have proven the assumption that lexis reflects cultural differences in the most obvious manner. I shall highlight to what extent the Chinese image of the world is indicated by the selection of entries by quoting selected words in the following semantic subfields: Leisure, recreation, entertainment; Travel (in the Everyday life group); Personal and social relations; Identity and work; Social relations; Culture and art (in the Social life group).

In the Leisure... subfield, what is noticeable is the number of entries which refer to kinds of tea and the brewing ceremony, a fact which indicates the role of the beverage in Chinese culture: chaye - tea leaves; Qimen hongcha - Keemun black tea; wulungcha - oolong tea; Huangshan maojian - tea from the Yellow Mountains; dawancha - tea served in a large cup; chadao - tea brewing ceremony; jingcha - ceremonial serving of tea; pincha - to taste tea. Words which refer to café reality do not display many differences when compared to their Polish counterparts.

Among the names of games, the most noteworthy include: majtang - mahjong; Zhongguo xiangai - Chinese chess; tiaoqi - Chinese checkers ${ }^{4}$.

This subfield also includes vocabulary denoting versions of ceramics from various shops, e.g.: geyao - porcelain from the Ge shop; dingyao - porcelain from the Ding shop; nunyao - porcelain from a folk shop. Other entries typical for the Chinese culture found in this subfield are, e.g.: chaozhu - official beads in ancient China; zhujian - connected bamboo boards onto which text was inscribed; caihui bohua - a painting on silk; xunzangpin - items placed in graves ${ }^{5}$.

The subfield Travel, under entries denoting travel stages and destinations, also includes the following words: sai longzhou - a dragon boat race; longdeng - a dragon lantern; shiwu - a lion dance. Indirectly, travel is also referred to in the following entries: gongfei hiyou - official business trip with elements of tourism and/or entertainment; guanguangtuan - a group engaged in joint sightseeing; ziyou huodong - time for one's own activities during a trip. This group also includes various terms denoting different types of hotels, e.g.: shangye luguan - a business hotel; liansuo luguan - a chain hotel; jijie yingye luguan - a seasonal hotel. People working in a hotel, e.g.: zhudian jingli - the manager of a hotel living in it permanently. The group of names denoting types of hotel rooms and beds includes interesting words, e.g. one denoting a luxurious bed, i.e. haohuachuang;

\footnotetext{
${ }^{4}$ A folder celebrating the Życie wśród piękna. Świat chińskiego uczonego [Life In Beauty. The World of Chinese People of Science] exhibition (the National Museum in Warsaw 1 Oct 2016 - 8 Jan 2017) included the names of old Chinese strategic games, e.g.: go, xiangqi chess, and shuanglu chess, known as "double army". "They gave learned officials not only entertainment, but they were also viewed as a tool for self-improvement helping them achieve the state of calmness and focus" (op. cit.).

${ }^{5}$ Including the quoted words in this subfield may seem unjustified as the following group (2) includes the subfield Culture and art, but I shall not discuss this issue in this article.
} 
a special word is used to denote a trip to a place associated with the history of the $\mathrm{CCP}$ - hongse luyou. A traveller must also learn the Chinese names of museums and historical sites, e.g. Zijinching i.e. the Forbidden City.

In Group 2 (Social life) the first subfield is Personal and social relations; its most noteworthy items include the names of family relations particular to China, e.g.: dinu - first daughter; shunu - second daughter; waipo - grandmother on mother's side; waigong - grandfather on mother's side; waizengzufu - great grandfather on mother's side; waizengzumu - great grandmother on mother's side; gege - older brother; jiejie - older sister; didi - younger brother; meimei - younger sister ${ }^{6}$. Those words reflect the hierarchy in the Chinese family of old, hence the doubt as to how well they are known by the modern Chinese since the transformations at the turn of the 21 st century altered the internal structures and relationships in families: "The Chinese family of old is no more. (...) Family clans have lost all their power. Migrations have segmented and weakened them. Families have become smaller, first through a ban on polygamy, and later by problems with access to living quarters and the need to search for jobs far away from home" (Jacoby 2016, p. 140).

The subgroup Identity and work includes lexis which reflects labour and official relations, e.g.: mingong - a worker from the countryside working in a city; liuxuesheng - a student studying abroad; zhuguan hush - a nurse assigned to a patient; dushengzinuzheng - certificate of having a single child; Gang-Ao longxingzheng - a pass to Hong Kong and Macau; beipiao - a person who lives and works in Beijing but is not domiciled in the city; guan erdal - the second generation of officials.

A major part of subfield 4. Culture and art consists of the names of Chinese musical instruments and styles of singing; consider a few examples: pipa (a Chinese musical instrument resembling a lute); matonquin - a Chinese musical instrument; miuzu changfa - folk mode of singing; yuanshengtai changta - original singing; yinyue wudao shish - an epic poem presented through dance and song.

${ }^{6}$ The lexis related to family relations is quite complicated. Apart from names, there are also names denoting the order in which people were born, e.g. Second Sister, Third Sister... Eighth Sister. That nomenclature was typical for a period when multigenerational families still existed. It has survived until today mostly in works of literature. For example, in Mo Yan's novel entitled Big Breasts and Wide Hips, seven daughters have the following names: Laidi, Zhaodi, Lingdi, Xiangdi, Pandi, Niandi, Qiudi, which in Chinese means: the coming younger brother, the summoned younger brother, the called upon younger brother, the awaited younger brother, the expected younger brother, the longed-for younger brother, and the pleaded-for younger brother. Along with the names, the sisters are referred to in the novel using numerical determinations: "A foreign woman looked at each of my sisters in turn starting with Fifth Sister and Sixth sister, who had straw tags sticking up out of their collars. Then she looked at Fourth Sister, Seventh Sister, and Eighth Sister, who did not have tags" Mo 2007, p. 163. [English version: Mo Y., 2004, Big Breasts and Wide Hips, Arcade Publishing]

Brother born as the final child in the family was named the Golden Boy (Jintong), and his twin sister: Jade Girl (Yunü). In the novel, she was usually referred to as Eighth Sister. 
Special terminology also applies to opera: jingju - a Beijing opera; lianpu - the makeup in the traditional Beijing opera forming a face mask; xiaosheng - characters of young men; laodan - characters of old women; huadan - characters of young women; daomadan - characters of woman warriors. Various opera styles and centres specialising in them have their own names, e.g.: pingju-a ping opera; yuju - a yn (Henan) opera; qingjang - opera from Shaanxi; yueju - Guangzhou opera.

Writing techniques and the related tools (a brush, ink, paper and stone for pressing ink) were a major element of Chinese culture; I have selected only a few examples from this group: wenfang si bao - a brush for writing, ink, stone for pressing ink, and paper; yan - stone for pressing ink; xuanzhi - rice paper; miaohong - painting in red; maobi - a writing brush; yinwen - depressed writing. Specialists in Chinese culture emphasise that: "In the Chinese civilisation, beautiful writing, meaning not only the creation of content, but also the art of calligraphy, and fine expression, was valued highly. Every learned person had to possess those skills and perfecting them required many years of training, culminating in an official exam" (Sarek 2016, p. 136). The importance of those skills is indicated by the existence in Chinese of many idioms which refer both to writing fine works of literature, poems in particular, and a beautiful manner of expression, e.g.: to cough out pearls and spit nephrite, meaning 'to speak and write beautifully'; carved nephrites bound in pairs, meaning 'a perfect poem'; words like shards of nephrite falling from the sky, meaning 'to speak and write beautifully'; round like a pearl and clear like nephrite, meaning 'skilful and clear style'; shards of nephrites and shapeless pearls, meaning 'a beautiful and short poem' etc. (cf. Sarek 2016, pp. 136-141).

An overview of selected entries from several fields and subfields in the Chinese-Polish dictionary indicates the diverse aspects of Chinese culture within various areas of personal and social life, a kind of Chinese vision of the world. By taking note of and considering cultural content in its definitions, a thematic dictionary defines a culture, and makes it easier for people to discover and learn it. An analysis of words in selected thematic fields may constitute a starting point for lexical exercises in Polish.

The need to introduce the elements of Polish culture in teaching Polish in China and the related problems have been raised by teachers of Polish, and Chinese lecturers at Polish studies. The challenges in this respect are caused by a lack of knowledge about European culture as even matters obvious in Western culture require clarification in Asia. Lecturers need to know ways of explaining the considerable cultural differences between Poland and China. Li Yinan, a lecturer of Polish studies in Beijing, has listed the following issues which are problematic for Chinese students: etiquette in formal and informal situations, and the elements of everyday life, e.g.: clothing, food, accommodation, and transport. The latter 
require teachers not only to introduce thematic vocabulary, but also contextual and situational explanations, e.g. the appropriate clothing for a situation, as the average Chinese pays no attention to what they wear. Many explanations require the reading of Polish literature: "Some nouns denoting pieces of clothing, food or weapons are completely absent from Chinese culture. Then we seek out appropriate images and we show what those items look like. That is a fascinating journey for Chinese students, and sometimes an entire lesson looks like a journey through exotic ancient Poland" (Li 2012, p. 271).

Based on my teaching practice at the Polish Studies Institute at the university in Guangzhou, I can state that those matters should be supplemented with instruction, especially in later years of study, on the culturally-conditioned conventions of using various text genres, e.g. different conventions applicable to academic or official texts. Direction on text genres should be accompanied by stylistic exercises, e.g. focussing on the stipulation to avoid vivid means of expression in academic works, and detailing the modes of quoting, and creating footnotes, endnotes and bibliographies (that mainly applies to bachelor's theses prepared by 4th-year students).

The process of acquiring cultural competence takes a long time: it requires knowledge of various aspects of the other (foreign) culture, the ability to identify types of communicational events, as well as good skills in the proper utilisation of words which refer to history, traditions, customs, and family and professional relations. A thematic dictionary may constitute a good teaching aid in teaching a non-native language.

\section{BIBLIOGRAPHY}

Batko-Tokarz, B., 2008, Tematyczny podział słownictwa w Wielkim słowniku języka polskiego. in: P. Żmigrodzki, R. Przybylska (eds.), Nowe studia leksykograficzne 2, Kraków, pp. 31-48.

Batko-Tokarz, B., 2019, Tematyczny podziat słownictwa wspótczesnego języka polskiego. Teoria, praktyka, leksykografia, Kraków.

Garncarek P., 2005, Kultura w nauczaniu języka polskiego jako obcego-próba definicji, in: P. Garncarek (ed.), Nauczanie języka polskiego jako obcego i kultury polskiej w nowej rzeczywistości europejskiej, Warszawa, pp. 17-23.

Jakoby, M., 2016, Chiny bez makijażu, Warszawa.

Li Y., 2012, Po polsku nie tylko się mówi! Metodyka nauczania kultury polskiej w dydaktyce polonistycznej w Chinach, „Postscriptum Polonistyczne”, issue 2 (10), pp. 263-273.

Masoit I., Rutkovska K., Patiejūnienė E., 2007, Tematyczny słownik polsko-litewski, Vilnius.

Miodunka W. (ed.), 2004, Kultura w nauczaniu języka polskiego jako obcego. Stan obecny - programy nauczania - pomoce dydaktyczne, Kraków.

Mo Y., 2012, Obfite piersi, petne biodra, Warszawa.

Otwinowska B., 1990, Stowniki, in: T. Michałowska (ed.), Stownik literatury staropolskiej, Wrocław, pp. 778-783.

Sarek K., 2016, Symbolika nefrytu w języku i kulturze chińskiej, Warszawa. 
Standardy wymagań odnoszacych się do poszczególnych poziomów biegłości językowej w zakresie znajomości języka polskiego jako obcego, in: Dziennik Ustaw RP, Warszawa, 30 March 2016.

Zaręba L., Kochan B., 2002, Tematyczny słownik języka francuskiego dla początkujących, Kraków.

Zarzycka G., 2005, Linguakultura polska - próba opisu (na marginesie powstającego Podręcznego leksykonu kultury polskiej dla cudzoziemców), in: P. Garncarek (ed.), Nauczanie języka polskiego jako obcego i kultury polskiej w nowej rzeczywistości europejskiej, Warszawa, pp. 313-326.

Zarzycka G., 2008, Kultura, lingwakultura, socjokultura w nauczaniu języka polskiego jako obcego, in: A. Seretny, E. Lipińska (eds.), Rozwijanie i testowanie biegłości w języku polskim jako obcym, Kraków, pp. 143-160.

Zhang Wenying, Sun Shuxue, Ao Danna, Zou Yanyan (eds.), 2013, Chińsko-polski stownik tematyczny, Hong Kong.

Życie wśród piękna. Świat chińskiego uczonego. Folder from an exhibition at the National Museum in Warsaw, 1 Oct 2016-8 Jan 2017.

Żydek-Bednarczuk U., 2012, Kompetencja międzykulturowa w nauczaniu języka polskiego jako obcego, "Postscriptum Polonistyczne", issue 2 (10), pp. 19-30.

Elżbieta Sękowska

\section{SŁOWNIK TEMATYCZNY JAKO ŹRÓDŁO KOMPETENCJI KULTUROWEJ (NA PRZYKLADZIE SLOWNIKA CHIŃSKO-POLSKIEGO)}

Słowa kluczowe: kompetencja kulturowa, lingwakultura, socjokultura, nauczanie języka polskiego jako obcego, słownik tematyczny

Streszczenie. Celem artykułu jest omówienie słownika tematycznego wybranego języka (na przykładzie słownika chińsko-polskiego) jako pomocy dydaktycznej przydatnej w nauce danego języka i kultury. Poszukując miejsca słownika tematycznego w nauczaniu języka odwołano się do pojęcia kompetencji kulturowej oraz zagadnień związanych z jej wprowadzaniem w procesie dydaktycznym. Kompetencja kulturowa obejmuje bowiem słownictwo i wiedzę (lingwakultura) oraz reguły interpretacyjne i elementy realioznawcze z zakresu socjokultury. Zawartość tych obszarów kultury danej wspólnoty jest omawiana w glottodydaktyce polonistycznej w pracach teoretycznych oraz programach nauczania języka polskiego jako obcego. Ukierunkowanie tych działań znajduje się między innymi w standardach wymagań odnoszących się do poszczególnych poziomów biegłości językowej.

Słownik tematyczny może służyć jako jedno ze źródeł wprowadzania elementów kultury ze względu na zawartość słownictwa, ilustrującego odmienności danego języka i kultury. W charakterystyce słownika tematycznego chińsko-polskiego skupiono się na opisie makrostruktury, zawartości wybranych kręgów tematycznych oraz wskazaniu przydatności w doskonaleniu znajomości leksyki, ilustrującej swoistość rzeczywistości pozajęzykowej. 